\title{
ERRATUM
}

\section{Transnational Environmental Law in a Transformed Environment - ERRATUM}

\author{
Thijs Etty, Veerle Heyvaert, Cinnamon Carlarne, Bruce Huber, Jacqueline Peel \\ and Josephine van Zeben
}

doi:10.1017/S2047102520000175, published by Cambridge University Press on 21 May 2020

The original version of this article was published with some erroneous references. The correct versions of the affected references are shown below.

${ }^{21}$ G. Samvel, 'Non-Judicial, Advisory, Yet Impactful? The Aarhus Convention Compliance Committee as a Gateway to Environmental Justice' (2020) 9(2) Transnational Environmental Law, pp. 211-38.

22 I. Offor, 'Animals and the Impact of Trade Law and Policy: A Global Animal Law Question' (2020) 9(2) Transnational Environmental Law, pp. 239-62.

23 A. Čavoški, 'Science and Law in Environmental Law and Policy: The Case of the European Commission' (2020) 9(2) Transnational Environmental Law, pp. 263-95.

${ }^{24} \mathrm{~J}$. Ellis, 'Calculative Practices in International Environmental Governance: In (Partial) Defence of Indicators' (2020) 9(2) Transnational Environmental Law, pp. 297-321.

25 S. Varvastian \& F. Kalunga, 'Transnational Corporate Liability for Environmental Damage and Climate Change: Reassessing Access to Justice after Vedanta v. Lungowe' (2020) 9(2) Transnational Environmental Law, pp. 323-45.

${ }^{26}$ K. Bouwer, 'Lessons from a Distorted Metaphor: The Holy Grail of Climate Litigation' (2020) 9(2)

Transnational Environmental Law, pp. 347-78.

${ }^{30}$ Samvel, n. 21 above, p. 212.

31 Ibid., p. 232.

32 Offor, n. 22 above, p. 240.

${ }^{33}$ Introduced briefly in Offor, ibid., p. 248 and discussed in detail in Offor, ibid., pp. 248-59.

34 Ibid., p. 260.

${ }^{35}$ Ibid., p. 240 ('This section uses empirical research to reveal the continued dominance of trade in European policymaking and its negative impact on animal welfare').

36 Cavoški, n. 23 above, p. 263.

37 Ibid., p. 264.

39 Ibid., p. 293.

${ }^{40}$ Ibid., p. 294.

41 Ibid., p. 295.

${ }^{42}$ Ellis, n. 24 above, p. 297.

43 Ibid., p. 299.

44 Ibid., pp. 320-1.

${ }^{55}$ Varvastian \& Kalunga, n. 25 above, p. 323.

56 Ibid., p. 325.

57 Ibid., p. 326.

58 Ibid., pp. 326-7.

59 Ibid., p. 329.

${ }^{60}$ Ibid., pp. 329-30.

62 Ibid., p. 332. 


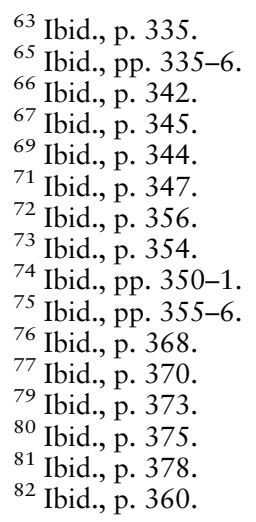

The errors have been corrected in the online PDF and HTML versions of this article.

Cambridge University Press apologises for these errors.

\section{Reference}

Etty, T., Heyvaert, V., Carlarne, C., Huber, B., Peel, J., \& Van Zeben, J. (2020). Transnational Environmental Law in a Transformed Environment. Transnational Environmental Law, 1-13. 